\title{
JANKO BORODÁČ A ANDREJ CHMELKO. DVE CESTY - JEDEN SMER
}

PETER HIMIČ

Fakulta dramatických umení Akadémie umení v Banskej Bystrici

Abstrakt: Štúdia sa zaoberá menej známymi reláciami medzi zakladatel’skými osobnostami slovenského profesionálneho divadla po 2. svetovej vojne. Vztah riaditela Východoslovenského národného divadla v Košiciach Janka Borodáča a umeleckého šéfa činohry Andreja Chmelka bol dlhodobo vnímaný ako umelecky previazaný, determinujúci len jedným smerom, s jasnou dominanciou Borodáča. Práca analyzuje umelecké aj ludské peripetie ich vztahu. Pomenúva prehistóriu oboch umelcov, ktorá sa v istom momente pretavila do rozhodujúcej etapy budovania košického divadla, na dlhé roky určujúcej umeleckú úroveň v podstate všetkých jeho súborov. Korelačné a diferenciačné momenty sú v práci zvýraznené najmä vo fokusovaní osoby Andreja Chmelka, ktorá sa neskôr stala determinujúcou pre vývoj košického divadla až do konca šest'desiatych rokov minulého storočia.

Klúčové slová: Janko Borodáč, Andrej Chmelko, Východoslovenské národné divadlo, Košice, realistická metóda, slovenská dráma a divadlo na východnom Slovensku po 2. svetovej vojne

Ked’ na 16. celoslovenských divadelných závodoch v Martine v novembri 1940 vystúpil v skupine mestských začiatočníckych krúžkov ochotnícky súbor Miestneho odboru Matice slovenskej z Kremnice s druhým dejstvom inscenácie Alexandra Vasilieviča Suchovo-Kobylina Krečinskij sa žení (réžia František Kudláč), predstavitel' titulnej roly Andrej Chmelko nemohol tušit', že stretnutie s umeleckým šéfom činohry bratislavského Slovenského národného divadla Jankom Borodáčom (členom poroty, tvorenej tiež Martinom Hollým, Jánom Martákom, Ivanom Turzom a i.), ktorý výstup sledoval v hladisku, sa mu stane osudným. Ani Jankovi Borodáčovi vtedy nenapadlo, že sa o pár rokov obaja stanú hlavnými hýbatel'mi profesionálneho divadla na východnom Slovensku. Že tak, ako v roku 1922 opúšţal Maršku aj Bratislavu, vracajúc sa na rodný východ na učitel'ský post do Sabinova, bude v roku 1945, už viac-menej nedobrovol'ne, odchádzat’ spolu s Chmelkom budovat’ slovenské divadlo a činohru do Košíc.

Je zrejmé, že Borodáčov vplyv na budúcu hereckú, režisérsku, dramaturgickú a riadiacu prácu Andreja Chmelka bol značný, v opačnom vztłahu to platilo v omnoho menšej intenzite. Slovenský divadelno-historický priestor túto koexistenciu vnímal (a v podstate dodnes vníma) jednoznačne ako vzt’ah učitel’a (Borodáč) a žiaka (Chmelko). Pri mnohých hodnoteniach počiatkov slovenskej profesionálnej divadelnej scény na východnom Slovensku nebolo možné abstrahovat’ od tohto vztahu, raz s dôrazom na zásluhy a vodcovstvo Borodáča v slovenskom divadle, inokedy akcentovaním jeho nespochybnitel’nej umeleckej a l'udskej skúsenosti ako zakladate- 
laa. Chmelkova pozícia bola z tohto pohl’adu logicky vnímaná ako komplementárna a subordinačne nevyhnutná. Len pre pripomenutie: v rokoch 1945 - 1953 mali obaja rozhodujúci vplyv na budovanie a umelecké smerovanie nového profesionálneho divadla v Košiciach ${ }^{1}$, Borodáč ako riaditel', Chmelko ako umelecký šéf činohry. $S$ odstupom času, s detailnejším štúdiom archívnych, umelecko-kritických a literárnych prameňov, je možné hlbšie analyzovat umeleckú tvorbu a zásadné rozhodnutia oboch divadelníkov aj ako riadiacich pracovníkov, ktoré na dlhé desatročia ovplyvnili podobu východoslovenského, najmä košického profesionálneho divadla. Ukazuje sa, že hodnotenie prvých ôsmich rokov košického divadla, ktoré sa dá označit’ ako borodáčovská éra, nemožno objektivizovat’ bez osoby Andreja Chmelka, bez poznania ich vzájomného l'udského a kolegiálneho vztahu, latentného či reálneho tvorivého dialógu, estetických názorov, bez poznania politických postojov a ideologických východísk, ktoré sú pre spomínané turbulentné obdobie príznačné. V Chmelkovom profesionálnom vývoji sú však z pohl'adu skúmanej problematiky aj fázy pred týmto obdobím, no najmä po ňom, ked’ prolongujú v podobe „borodáčovských tieňov“ (práce divadelných historikov a pamätníkov). Po jeho odchode na dôchodok (1968) sa tieto tiene viac predlžujú než skracujú.

S ohl'adom na menované skutočnosti sa prirodzene núka niekolko období a tém, ktoré rámcujú a profilujú tento, od počiatku „nerovný“, vzt̉ah. V diachrónnom zmysle sú to predkošické obdobie počas Slovenskej republiky 1939 - 1945, spomínané roky 1945 - 1953 a Chmelkova košická misia po roku 1953, vnútorne členená po Borodáčovu smrt' (1964) a Chmelkov odchod do dôchodku (1968). V umeleckej rovine sú to najmä ideové a estetické východiská, dramaturgicko-režijná práca, metodologické a štýlotvorné otázky, problémy súvisiace s formou a prácou s hercom, vztah k divadelnej teórii a kritike. Nemožno opomenút’ ani mimoumeleckú oblast', najmä s ohl'adom na rýchlo sa meniace štátne a politické pomery v priebehu pár desatročí. Napokon, obaja boli príliš dlho riadiacimi pracovníkmi i funkcionármi a boli obdobia, ked' stáli na opačných ideologických stranách. Širší záber výskumu umožňuje dosiahnut väčšiu plastickost’ fokusovania sledovaného materiálu a objektivitu výsledku.

Je zrejmé, že pre formovanie Chmelkovho umeleckého názoru boli klúčové práve roky intenzívneho kontaktu s Jankom Borodáčom v povojnových Košiciach. Borodáčov odchod z Bratislavy v roku 1945 nie je pre súčasnú slovenskú divadelnú históriu tabu. V hektickosti povojnových dní bol jedným z tých, ktorých pozícia v bratislavskom Národnom divadle ${ }^{2}$ bola d’alej neudržatel'ná. Poverenie vybudovat’ nové profesionálne divadlo na východe republiky sa zdalo byt’ kompromisným východiskom. Svoj pohlad na inkriminované obdobie ponúka aj samotný Borodáč, ktorý pocitoval vtedajšie útoky ako krivdu, zvlášt', ked' sa nepochopitel'ne dotýkali aj jeho manželky, herečky Ol'gy Borodáčovej-Országhovej. ${ }^{3}$ Andrej Chmelko bol ako riaditel'

${ }^{1}$ V roku 1945 vzniklo Východoslovenské národné divadlo, od sezóny 1946/1947 fungovalo pod názvom Národné divadlo v Košiciach, od sezóny 1955/1956 s krátkym prerušením až dodnes pôsobí pod názvom Štátne divadlo Košice (ŠDK). Tým prerušením bolo spojenie ŠDK s prešovským Divadlom Jonáša Záborského od 1. 1. 1996. Divadlo nieslo názov Východoslovenské divadlo (od 1. 10. 1996 Východoslovenské štátne divadlo), pričom košická čast’ sa volala Divadlo Janka Borodáča. Táto fúzia trvala do 30. 6. 1999.

${ }^{2}$ Názov, pod ktorým od marca 1942 do septembra 1958 pôsobilo Slovenské národné divadlo.

${ }^{3}$ BORODÁČ, Janko. Spomienky. Bratislava : Národné divadelné centrum, 1995. ISBN 80-85455-07-2. O zásadnú rehabilitáciu Borodáča v tomto smere sa v druhej polovici pätdesiatych rokov minulého storočia pokúsil prorežimistický teatrológ Rudolf Mrlian v knihe So slovenským divadlom. (MRLIAN, Rudolf. So slovenským 


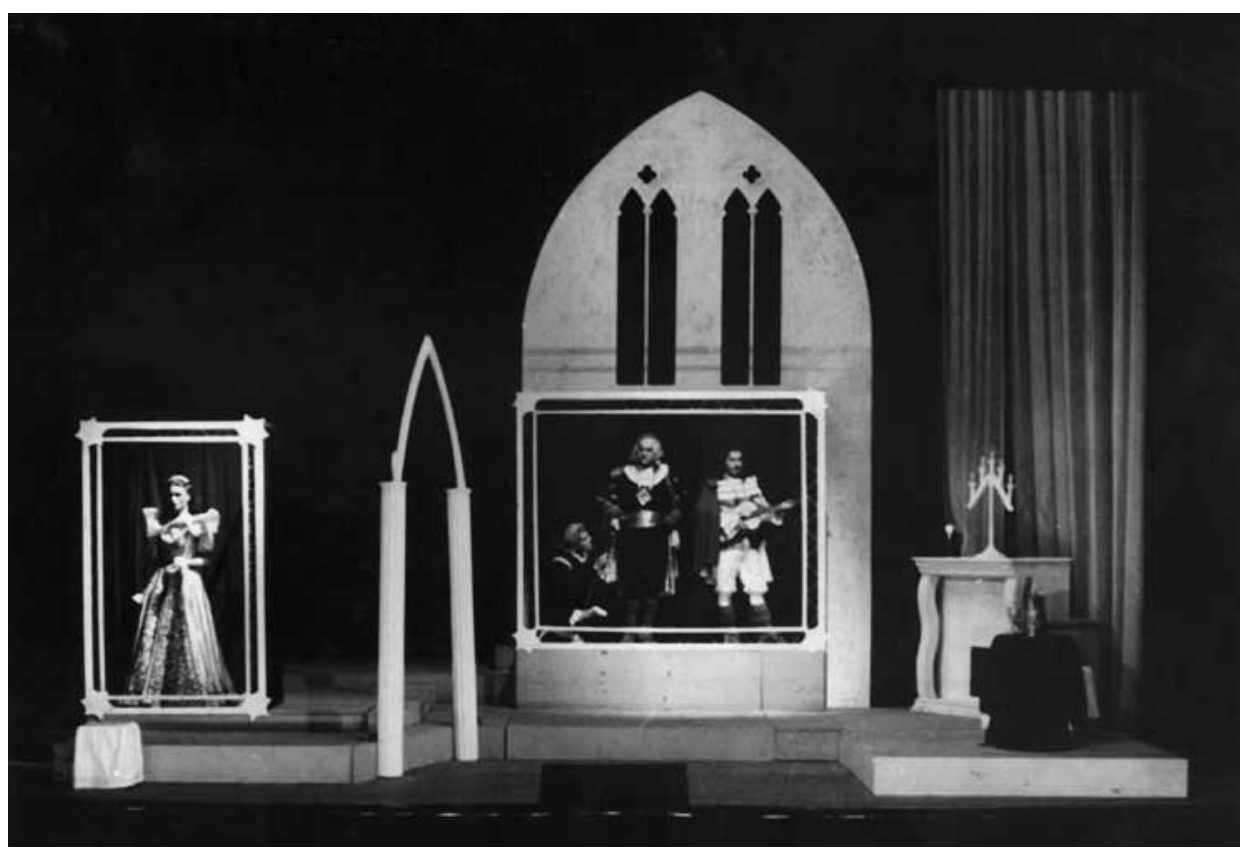

Peter Zvon: Tanec nad plačom. VND v Košiciach, premiéra 22. 6. 1946. Réžia Andrej Chmelko. Foto archív Štátneho divadla Košice.

vtedajšieho Slovenského divadla v Prešove vtiahnutý do otázok budovania nového košického divadla, ked’že v povojnovom pláne divadelnej siete Andreja Bagara, nového intendanta slovenských divadiel, bol Prešov vnímaný ako „farma“" pre Košice. ${ }^{4}$ Takto, ešte pred otvorením košického divadla, vstúpil Chmelko do d’alšieho kontaktu s Borodáčom. V júni 1945 sa totiž Chmelko na bratislavskej porade o novom usporiadaní divadiel a kádrovom prerozdelení v nich priklonil k myšlienke, že prejde do nového košického divadla na pozíciu umeleckého šéfa činohry, ak bude riaditelom Janko Borodáč. Na pripomienku, že aj Prešov chce mat’ svoje vlastné divadlo, panoval jednotný názor, „že Prešov má obhospodarovat' košické divadlo, ktoré povedie Ján Borodáč “5. Borodáčovi sa opät’ vytýkala jeho činnost’ počas Slovenskej republiky, od kooperácie s režimom až po alibistickú rezignáciu. Borodáč „ponuku“ prijal. ${ }^{6}$

divadlom : Životné dielo Janka Borodáča a Ol'gy Borodáčovej-Országhovej. Bratislava : Slovenské vydavatel'stvo krásnej literatúry, 1957.) Ako konštatuje divadelný historik Karol Mišovic, ide však o „privelmi idealizovaný a najmä ideologicky zafarbený pohl'ad“, ktorý navyše obsahuje „početné faktografické omyly a predovšetkým zavádzanie" smerom k jeho politickým postojom počas Slovenskej republiky 1939-1945, a preto sa Mrlianova práca „nedá pri analýze Borodáčovej osobnosti považovat za objektívny zdroj informáciï“. In MIŠOVIC, Karol. Ján Borodáč a jeho prvé kroky v živote i v divadle. In Slovenské divadlo, 2017, roč. 65, č. 2, s. 101.

${ }^{4}$ Viac pozri HIMIČ, Peter. Divadelný život Prešova : Od počiatkov do polovice 20. storočia. Bratislava : Divadelný ústav, 2014. ISBN 978-80-89369-77-5.

${ }_{5}^{5}$ CHMELKO, Andrej. Divadlo na východnom Slovensku : Historický náčrt. Košice : Východoslovenské vydavatel'stvo, 1971, s. 97.

${ }^{6}$ Viac k tejto časti textu pozri HIMIČ, Peter. Janko Borodáč - zakladatel' alebo exulant? In ŠUTAJ, Štefan (ed.). Ludia a dejiny - historická biografia a jej miesto v historiografii [zborník príspevkov z vedeckej konferencie]. Košice : Filozofická fakulta Univerzity Pavla Jozefa Šafárika, 2016, s. 120 - 125. ISBN 978-80-8152-427-1. 
Východoslovenské národné divadlo v Košiciach vzniklo ako štátne. Štruktúra bola v prvých povojnových predstavách (Andrej Bagar) načrtnutá ako „predbežne“ jednosúborová: „Súbor opery ND z Bratislavy jednomesačným zájazdom (...) by zapĺňal predbežne medzeru v tomto odbore. Neskôr sostavila by sa v Košiciach tzv. malá opera (...). ${ }^{\prime 7}$ Inú predstavu mal povereník Ladislav Novomeský, ktorý - podl’a Chmelka - poveril Borodáča „vybudovaním druhého národného divadla so všetkými súbormi (činohrou, operu a baletom) “8. Borodáč vo svojich Spomienkach tvrdí, že sa s Novomeským rozišiel „,bez podrobnejšieho dohovoru o rozsahu a obsahu budúceho divadla v Košiciach. Celú vec ponechal na mňa. ${ }^{\prime 9}$ Bola to tažká úloha. Predovšetkým personálne obsadenie všetkých, aj neumeleckých pozícií bolo vel'kým otáznikom. Košice napokon začali budovat druhé národné divadlo s klasickou štruktúrou súborov, ako to bolo aj v bratislavskom ND. Len čas a umelecké kvality mali preverit', či to nebol príliš ambiciózny plán.

Pozícia Janka Borodáča nebola priaznivá ani v Košiciach. Niektorí predstavitelia miestnej inteligencie prejavovali nespokojnost’ s jeho príchodom. Borodáč nepatril k politickým exponentom l’udáckeho režimu, ale jeho povolanie a funkcia boli príliš viditelnými. Napriek tomu bola reakcia košickej tlače voči Borodáčovi príliš krutá: „Už dávnejšie pozorujeme, ako prichádzajú do Košíc vždy viacerí a viacerí l’udia, ktorí sa silne exponovali za Tisov režim a mnohí sa pretekali v spolupráci s Nemcami. (...) Dopočúvame sa, že je už na ceste do Košíc bývalý riaditel’ Národného divadla v Bratislave, ktorý nemá čistý štít, Janko Borodáč, aby prevzal v Košiciach funkciu riaditela košického divadla. (...) I nech sú títo páni na slovo vzatí odborníci (...) Košice potrebujú ludí s čistým politickým štítom, l’udí protifašistického smýšlania (...) mladí zaslúžilí l’udia by stopercentne nahradili všetkých tých starých ,odborníkov', ktorí sa skompromitovali kolaborantstvom s nemeckými a slovenskými fašistami. “10 Väčšina článkov bola nesignovaná, a tak nemožno potvrdit Chmelkovo tvrdenie, že kvôli dôveryhodnosti „,̌lánky podpisuje miestny odbor Matice slovenskej v Košiciach"11. Naopak, jeho osobná intervencia vo Východoslovenskej Pravde bola úspešná: „Slúbili mi, že zastavia kampaň, ale s podmienkou, že si s Borodáčom po jeho nástupe veci vykonzultujú. "12 Chmelko taktiež píše, že články pripravovali oba vládne denníky, popri Východoslovenskej Pravde aj Demokrat. Ani túto informáciu však vydania Demokratu nepotvrdzujú, ba práve naopak. „Pre východ je zvlášt potešitelné, že do divadla zavíta Janko Borodáč, bývalý šéf činohry ND v Bratislave“13, píše sa v denníku. Iné vydanie víta Borodáča, "ktorý ako osvedčený pracovník na tomto poli je zárukou, že (...) splní na východnom Slovensku svoju významnú umeleckú a národnú úlohu“"14. Dnes je už t’ažko určit’, kto stál za článkami. „Jeden napísal

\footnotetext{
Skrátená verzia príspevku vyšla aj vo FERKO, Tibor. Divadelné letopisy mesta Cassa, Caschau, Kassa, Košice v súvislostiach dejín 1557 - 1945 - 2015. Košice : EQUILIBRIA, 2017, s. 989 - 992. ISBN 978-80-8143-194-4.

${ }^{7}$ BAGAR, Andrej. Stručný návrh na riešenie divadelnej otázky povojnového Slovenska. In Naše divadlo, 1945 , roč. 17, č. 1 , s. 8 .

${ }^{8}$ CHMELKO, Andrej. Divadlo na východnom Slovensku, s. 138.

${ }^{9}$ BORODÁČ, Janko. Spomienky, s. 235.

${ }^{10}$ Autor neuvedený. Majú byt' Košice exilom? In Východoslovenská Pravda, roč. 1, č. 112, s. 4, 11. 7.1945.

${ }^{11}$ CHMELKO, Andrej. V zajatí Tálie. Bratislava : Slovenský spisovatel', 1989, s. 75.

${ }^{12}$ Tamže.

${ }^{13}$ Autor neuvedený. Bratislavská „Národná obroda“... In Demokrat, roč. 1, č. 61, s. 3, 21. 7. 1945.

${ }^{14}$ Autor neuvedený. Pred sezónou Národného divadla v Košiciach. In Demokrat, roč. 1, č. 73, s. 3 , 17. 8. 1945.
} 
ašpirant na riaditel’ské miesto a druhý politický činovník“15, spomínal po rokoch Janko Borodáč.

Andrej Chmelko bude neskôr často spomínat', ako uchránil riaditel’a pred nástrahami politickej moci. Ako je známe, Janko Borodáč nikdy nevstúpil do komunistickej strany (ani do žiadnej inej), čo najmä po Februári 1948 nebolo pri exponovanej, ideologicky sledovanej funkcii zvykom. Popri pevnej odhodlanosti neangažovat' sa politicky, zvlášt po skúsenostiach z vojnového obdobia, to bola zrejme aj sila Borodáčovej všeobecne akceptovanej zakladatel'skej osobnosti. Komunistický prevrat v roku 1948 a nasledujúce roky stalinizmu otupovali tento nimbus. Naopak, Chmelko bol prvým predsedom akčných výborov komunistickej strany, ktoré politicky preverovali zamestnancov inštitúcií, neskôr predsedom strany v divadle, členom okresného výboru a funkcionárom na mestskej a okresnej úrovni. Ked' na začiatku sezóny 1948/1949 ponúkol Borodáčovi prihlášku do komunistickej strany, ten ju odmietol: „Nikdy som nebol v žiadnej strane, radšej nie, ani teraz... Ak ma odvolajú, nuž nech odvolajú..." ${ }^{\text {16 }}$ Andrej Chmelko ako presvedčený komunista bol aj neskôr v rozpore s týmto Borodáčovým stanoviskom a niekol'kokrát sa pokúšal presvedčit riaditela (zrejme na základe straníckej úlohy), aby ponuku prijal. Naviac, na konci predchádzajúcej sezóny sa miestne štruktúry strany angažovali v odvolaní Borodáča z funkcie riaditel’a, najmä poslanec Oskár Jeleň, ked’že ho „nemožno usmerňovat’ (...) herec to nie je, v tej Poslednej prekážke sklamal celé mesto, a režisér...? (...) aby nám servíroval také divadlo ako v Bohatej žene! (...) Všetci demokrati sa chodia rehotat', akú karikatúru urobil z kolchozu! “17 Andrej Chmelko, napriek vyhrážkam o straníckej úlohe a organizovanom tlaku zdola, ponúkanú funkciu riaditela navonok odmietal. Nebol si celkom istý svojou pozíciou, ked’že miestne stranícke štruktúry žiadali aj o riaditel’a z Bratislavy. „Ako neskôr vysvitlo, on [Andrej Chmelko, pozn. P. H.] vraj o to neprosil, ale ponuku neodmietol“18, postažoval si Borodáč. Chmelko tiež vedel o Novomeského podpore Borodáčovi, čo sa napokon o pár týždňov potvrdilo, ked’ Novomeský na požiadanie Borodáča osobne pricestoval do Košíc, aby spor vyriešil. Taktizovanie z Chmelkovej strany aj spomínané stranícke „kortešačky“ ostali do konca Borodáčovho košického pôsobenia zdrojom nedorozumení. ${ }^{19}$

Je potrebné pripomenút', že Janko Borodáč hral významnú úlohu pri zvolení

${ }^{15}$ BORODÁČ, Janko. Spomienky, s. 243. Dnes je tažké rekonštruovat', ako prebiehala spomínaná „konzultácia“ a kto mal záujem o riaditel’ské miesto, ale o mesiac už Východoslovenská Pravda konštatuje: „Našou povinnostou je povedat’ niekolko slov i o našich vzt’ahoch k osobnosti riaditela divadla Borodáča: Svoje úsilie, ktoré vyvinul za slovenskost’ Národného divadla v Bratislave, dostatočne odôvodnil slovami: Lúbit' svoje a konat' svoju povinnost', neznamená nenávidiet druhého." (Pozri (bez uvedenia autora). Pred otvorením Národného divadla v Košiciach. In Východoslovenská Pravda, roč. 1, č. 145, s. 4, 19. 8. 1945.) Borodáč neostal ušetrený ani rok po svojom nástupe do Košíc. Riaditel’ prešovského Slovenského divadla František Rell mu nikdy nezabudol, že v roku 1944 pred ním uprednostnil Andreja Chmelka ako prvého riaditel’a prešovského divadla. Pri druhom výročí Slovenského národného povstania o činnosti bratislavskej činohry počas vojny napísal: „(...) ND v Bratislave malo na programe autorov, ktorí boli priam iniciátormi rasizmu a nacizmu (....). Pozri NOVOHRADČAN, Fero [RELL, František]. Slovenské divadlo v Prešove a národný odboj. In Hlas l’udu, roč. 2, č. 192, s. 6, 29. 8. 1946.

${ }^{16}$ CHMELKO, Andrej. V zajatí Tálie, s. 110.

17 Tamže, s. 108.

${ }^{18}$ BORODÁČ, Janko. Spomienky, s. 250.

19 „Neraz sa navzájom osočovali, aby si potom zasa padali do náručia a jeden druhému utierali slzy odpustkov." Pozri BZDÚCH, Ján. Ošl'ahnutý oponou. Bratislava : Národné divadelné centrum, 1997, s. 87. ISBN 80-85455-34-X. 


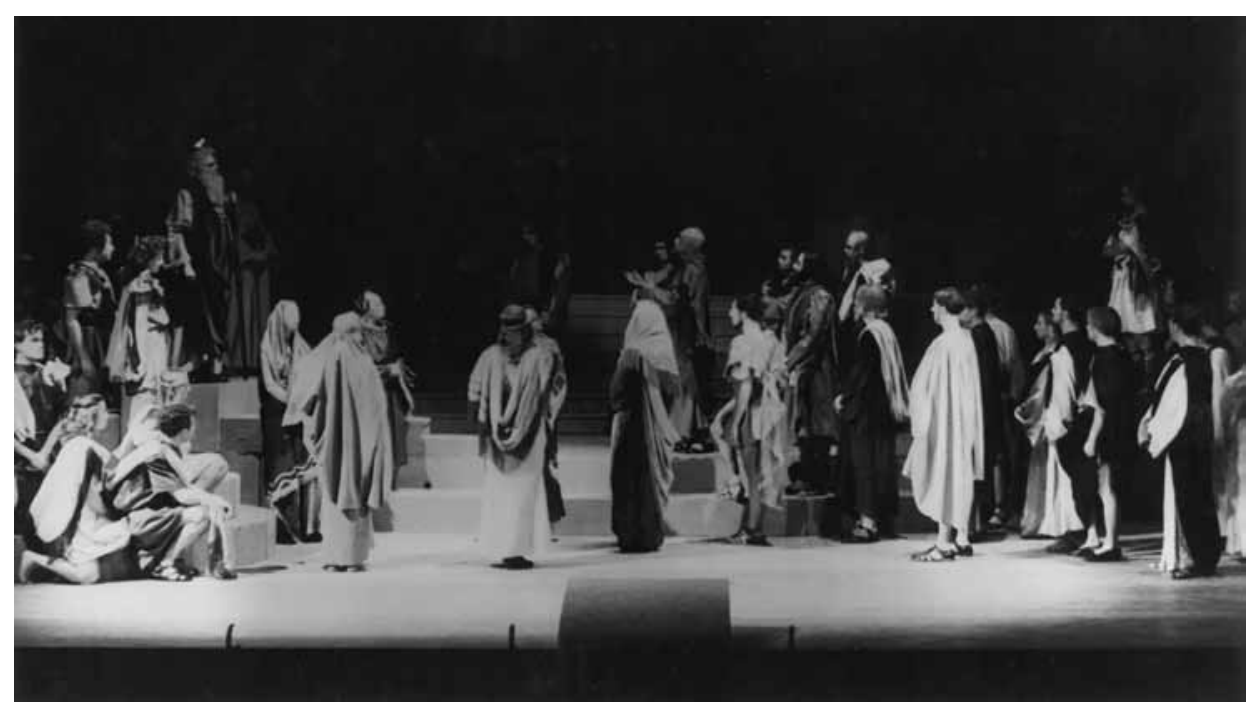

Július Barč - Ivan: Veža. ND v Košiciach, premiéra 20. 9. 1947. Réžia Andrej Chmelko. Foto archív Štátneho divadla Košice.

Andreja Chmelka za prvého riaditel’a Slovenského divadla v Prešove. Ten na to vo svojich pamätiach spomína: „Anton Prídavok sa obrátil na Borodáča, aby poradil riaditela. Ešte pred dovolenkou nás v byte navštívil Borodáč a presviedčal ma, aby som prevzal miesto v Prešove. “20 Kandidátov bolo viac. Prídavok navrhoval aj seba, potom Borodáča, neskôr Ondreja Jariabka. „V lete ma potom pozval sám Prídavok do Korytnice, kde sa liečil, a tiež naliehal. ${ }^{\text {} 21}$ Borodáčova podpora Chmelkovi však mala širšie súvislosti: „Vedenie prešovského súboru prevzal člen činohry SND, ktorý nemal dobrú pozíciu v Bratislave. Jeho žena už prv dostala výpoved, a jeho čakal podobný osud. “22

Andrej Chmelko bol rozhodnutý odíst’ z ND tak či tak. Jeho prvé kroky však smerovali do Martina, do Matice slovenskej, kde už mal dohodnuté pracovné podmienky na novej pozícii. Príprava Chmelka na „lepšiu“ pozíciu bola teda viac otázkou jeho individuálneho problému než výsledkom koncepčného uvažovania o charaktere a ideovom smerovaní nového divadla. ${ }^{23}$ Borodáč nemohol v období okolo Februára

\footnotetext{
${ }^{20}$ CHMELKO, Andrej. V zajatí Tálie, s. 42.

${ }^{21}$ Tamže.

${ }^{22}$ BORODÁČ, Janko. Spomienky, s. 223. Gizela Chmelková (manželka Andreja Chmelka) odišla z ND k 15. 8. 1943. Podl’a návrhu na rozviazanie pracovných pomerov, ktorý Ministerstvu školstva a národnej osvety predložil štátny intendant Karol Laštuvka, patrila Chmelková k skupine hercov, „s ktorými už správa divadla sama nepočítala“. Chmelko sa snažil už po druhýkrát o odchod z divadla (sezónu predtým riešil problém so svojím odchodom, výsledkom bolo, že - paradoxne - vtedy manželku do činohry ND prijali). Viac pozri List SND Ministerstvu školstva a národnej osvety z 2. júla 1943: Rozviazanie pracovných pomerov v SND. In LAJCHA, Ladislav. Dokumenty SND 1939 - 1945 : Divadlo v rokoch vojny. Bratislava : Divadelný ústav, 2000, s. 362 - 363. ISBN 80-88987-17-2.

${ }^{23}$ Andrej Chmelko vo svojich spomienkach hovorí aj o tom, že ešte pred ním bol post riaditela SD ponúknutý Jánovi Jamnickému, Ivanovi Lichardovi a Karolovi Želenskému. Táto ponuka pravdepodobne vychádzala od zástancov Prídavkovej a Borodáčovej koncepcie. Pozri CHMELKO, Andrej. V zajatí Tálie, s. 42.
} 
1948 nemysliet’ na tieto fakty, aj na povolanie Chmelka po vojne z prešovskej zálohy. Chmelkove riaditel'ské ambície v roku 1948 ho nemilo prekvapili. Je možné, že aj to bol jeden $\mathrm{z}$ dôvodov, prečo ho hned' v nasledujúcom roku ako člen výboru Dramaturgickej a divadelnej rady odporúčal za prvého riaditel’a novovznikajúceho zvolenského divadla (uprednostnil ho pred druhým kandidátom, Ivanom Lichardom). Chmelko však, napriek vyhrážkam o vyhodení z divadla, ponuku neprijal, čo Borodáča prekvapilo, ked’že mal už vyhliadnutého jeho nástupcu - Jána Klima. ${ }^{24}$ Tento fakt, naopak, prekvapil Andreja Chmelka. Narastajúce napätie medzi oboma bolo cítił čoraz viac a presahovalo i za múry košického divadla. ${ }^{25}$ Ked' v roku 1950 vznikol pri košickej činohre ako pobočka bratislavského Štátneho konzervatória dvojročný Odborný divadelný kurz s právom udel'ovat’ vysvedčenia (ekvivalent absolutória z konzervatória), zostavením pedagógov bol poverený Chmelko. Borodáč, zakladajúci pedagóg Hudobnej a dramatickej akadémie pre Slovensko z dvadsiatych rokov, to bral osobne, a tak Chmelkovu ponuku na učenie neprijal.

V roku 1952 sa situácia okolo Borodáča ako riaditela-nestraníka nad’alej zhoršovala. V júni sa naviac dožíval šest’desiatky, takže mohol byt’ penzionovaný aj bez podozrení z ideologickej ofenzívy voči jeho osobe. Na druhej strane si politická moc uvedomovala jeho zásluhy pri zakladaní a budovaní slovenského profesionálneho divadla. Napriek tomu prebehlo na jar 1952 kádrové posudzovanie, ktoré malo viac-menej dopredu pripravený výsledok. Padlo rozhodnutie o ukončení Borodáčovej funkcie v Košiciach, pochopitel’ne, s náležitými poctami pri príležitosti jeho životného jubilea. Andrej Bagar ho oslovil na miesto pedagóga Vysokej školy múzických umení, čo Borodáč vnímal ako odsun od režisérskej práce.

Ostávala posledná úloha, nájst' nového riaditel’a. Okresné stranícke štruktúry presadzovali skôr neprofesionála, mal byt’ však nomenklatúrne osvedčený. Borodáč sa najprv snažil preniest' zodpovednost' na povereníctvo, zdráhal sa označit svojho nástupcu z domáceho prostredia („Nevedel som sa rozhodnút', lebo som poznal všetkých, až vel’mi dobre. ${ }^{26}$ ), prikláňal sa k bratislavským zdrojom. Tie však, údajne na

\footnotetext{
${ }^{24}$ Andrej Chmelko to mal prijat ako stranícku úlohu, dokonca sa zúčastnil konkurzu na herecké miesta v novom súbore už ako dezignovaný riaditel. Až po osobnej intervencii u Andreja Bagara (predsedu konkurznej komisie), ktorý mu odpovedal: „Nežijeme vo feudalizme, aby sme niekoho nútili. Ak záujem nemáš, odmietni!", napísal Ladislavovi Novomeskému negatívnu odpoved'. Pozri CHMELKO, Andrej. V zajatí Tálie, s. $120-121$.

${ }^{25}$ Ján Bzdúch spomína, ako raz vo vlaku stretol Andreja Bagara: „A čo tí dvaja vystrájajú?, pýta sa ma. Nuž i oni počas divadelných prázdnin šli na ROH školenie, a to na dvojtýždňové, vravím. Spolu? Áno. Po pauze plasol ma svojou dlaňou po stehne a s vel'kým smiechom priam zakričal. To si tam tí dvaja kohúti budú musiet’ tykat!"“ (BZDÚCH, Ján. Ošl’ahnutý oponou, s. 87.) Niekol'kokrát museli spory riešit’ aj na miestnej a regionálnej úrovni, zvlášṫ začiatkom pätdesiatych rokov, ked’ sa stupňovali tlaky proti Borodáčovi zo strany niektorých popredných funkcionárov KSČ. Takým bol napríklad Ján Grünwald, dramaturg opery, ktorý brojil proti „panovačnému“ riaditel’ovi, ale aj proti šéfovi opery Tiborovi Frešovi, a zakladal tzv. umelecké brigády. V spomínanom období musel Borodáč čelit’ aj donášačstvu a kriminalizovaniu niektorých zamestnancov zo strany ich podriadených.

${ }^{26}$ BORODÁČ, Janko. Spomienky, s. 271. Na tomto mieste je potrebné spomenút obsahové rozdiely v dvoch vydaniach Borodáčových memoárov. Vo vydaní z roku 1975 (týkalo sa iba obdobia 1945 - 1964) redaktor Julo Zborovjan, zaiste po konzultáciách s majitel'kou práv na vydanie strojopisného originálu Ol'gou Borodáčovou-Országhovou, vynechal niekolko pasáží, ktoré v období vrcholiacej normalizácie v komunistickom Československu mohli byṫ citlivé pre svoje nekompromisné konštatovania, aj smerom k ešte žijúcim osobám. Napríklad práve pejoratívne ladená čast' vety ",som poznal všetkých, až vel’mi dobre“ je v Zborovjanovej redakcii eufemisticky prepísaná na „....všetkých už vel'mi dobre“. Pozri BORODÁČ, Janko. Pamäti (1945 - 1964). Košice : Východoslovenské vydavatel'stvo, 1975, s. 59.
} 


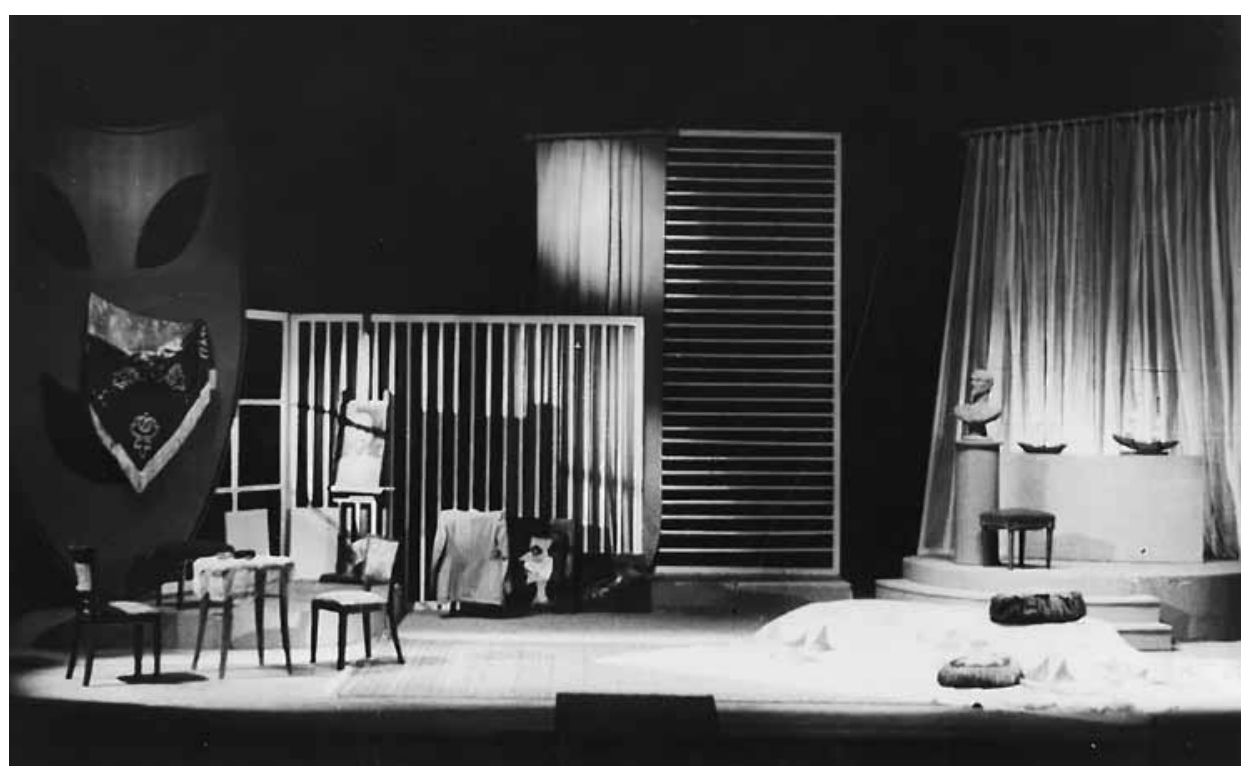

Luigi Pirandello: Hladaj seba. ND v Košiciach, premiéra 17. 1. 1948. Réžia Andrej Chmelko. Scéna Ladislav Šestina. Foto archív Štátneho divadla Košice.

návrh Jozefa Budského, navrhli Andreja Chmelka²7, čo nebolo v súlade s Borodáčovou predstavou. Vo svojich Spomienkach to komentoval slovami: „Chcel byt riaditel’om, nuž stal sa ním. “28 Tak sa skončil ich osemročný, spočiatku sl’ubne sa rozvíjajúci, neskôr napätím poznačený subordinačný vzt’ah. Borodáčov tieň však sprevádzal nového riaditel'a ešte dlhé roky.

Formovanie ideových a estetických rámcov divadelníka Andreja Chmelka nebolo od jeho vstupu na scénu SND determinované len osobou Janka Borodáča. Chmelko bol jedným z mnohých, ktorí v tých rokoch prichádzali z ochotníckeho prostredia, aby personálne doplnili absolventov bratislavskej akadémie. Treba tiež poznamenat', že spočiatku nebol hercom „telom i dušou“. K divadlu ho priviedla náhoda. Začínal ako šepkár v ochotníckom krúžku v rodnom Hliníku nad Hronom a neskôr, v období kremnického učitel'ského pôsobenia, jeho herecký naturel využil kolega František Kudláč. Na tomto mieste spomeňme, že Andrej Chmelko aj v budúcnosti, najmä $\mathrm{v}$ dôsledku hereckých neúspechov a personálnych problémov, intenzívne uvažoval o návrate k pedagogickej práci. Svoj záujem smeroval k literatúre, otázkam slovenčiny, niekol'kokrát sa pokúsil teoreticky prispieł do problematiky ortoepie, javiskovej reči, ba aj divadelnej teórie, histórie a kritiky. Neskôr vstúpil na pôdu umeleckej literatúry ako autor (román, divadelné hra, dramatizácie, preklady, memoárová literatúra), no nikdy s výraznejším dosahom.

${ }^{27}$ CHMELKO, Andrej. $V$ zajatí Tálie, s.147. Na miesto umeleckého šéfa činohry rátali s Ivanom Lichardom, čo sa nikdy nestalo.

${ }^{28}$ BORODÁČ, Janko. Spomienky, s. 272. V Zborovjanovej redakcii z roku 1975 táto poznámka, ktorá signifikantne demonštruje Borodáčov názor na Chmelkove ambície, úplne chýba. 
V štyridsiatych rokoch Chmelko chvíl’u váhal prijał’ Borodáčovu ponuku stat’ sa členom činohry Slovenského národného divadla. Zovretie gardistických síl však dolahlo aj na školské prostredie a bolo rozhodnuté. Dalo by sa povedat', že najmä v čase bratislavských hereckých začiatkov bol Chmelko samorastom bez väčších uvedomení si podstaty hereckej práce, jej techník, javiskových možností a, pochopitelne, i bez väčších znalostí moderných prúdov vo vtedajšom európskom divadle. Aj ked' debutoval u Jána Jamnického (Stenzel v Hauptmannovom Kolegovi Cramptonovi (1941), neskôr v jeho réžiách vytvoril Demetria v Sne noci svätojánskej (1942), Waltera v Rozbitom džbáne (1943) či Predsedu promócie v Zdravom nemocnom (1943)) a častejšie ho obsadzoval Borodáč ${ }^{29}$, najväčšiu príležitost’ dostal od Ivana Licharda (v ND účinkoval iba v jedinej jeho inscenácii) ako Helmer v Ibsenovej Nore. Helmer bol zároveň jeho najväčším sklamaním $^{30}$ a po Nore sa začal intenzívne zaoberat' myšlienkou odchodu $\mathrm{z}$ divadla.

Andrejovi Chmelkovi imponovala režisérska práca Janka Borodáča - „tvrdé pracovné tempo“ (Ostrovskij: Vlci a ovce), „železná disciplína“ na skúškach, kde režisér neznášal „ani úsmev v nevhodnú chvílu“" (Stodola: Marína Havranová). Aj ked’ ho Jamnického režisérske postupy a umelecké názory zaujímali, nedokázal v nich vidiet väčší zmysel: raz to bol preňho iba nekoncepčný pokus (,,Z jeho ,pokusníctva' som tu nevidel nič, ešte aj gesto predhrával. Čistý realizmus. ${ }^{\text {“31 }}$ ), inokedy nechápal roztiahnutie dramatického priestoru mimo javiska, napríklad, ked’ Viliam Záborský v Poničanovej hre Štyria recitoval autorské básnické vložky na galérii. ${ }^{32}$ Jamnického réžie museli pre tradične orientovaného, bývalého ochotníckeho herca pôsobit’ príliš modernisticky. Klasické chápanie zložiek inscenačnej štruktúry, s dôrazom na "posvätnost”“ autora a dramaturgicky ustálený ideovo-estetický koncept, sa dostávalo do rozporu s experimentovaním s akustickými výrazovými prostriedkami herca a náznakovými scénickými riešeniami. Vo svojich bratislavských začiatkoch však bral na milost' novú (v slovenských podmienkach) funkciu svetla, zbaveného komplementárnosti a chronotopového určenia, ako napríklad vo Viliamovi Tellovi, v ktorom výtvarník Emil Belluš s režisérom Jánom Jamnickým siahli „k bohatému použitiu svetla, lúčov “33. Chmelko, poučený Jamnického prácou predovšetkým vo výtvarnom riešení inscenácií, neskôr vo svojich réžiách inklinoval k symbolizmu a miernemu poetizmu. Dôkazom sú niektoré jeho práce z prešovského obdobia a z úvodných rokov košického pôsobenia.

Prvé profesionálne sezóny Andreja Chmelka v Bratislave umelecky ovplyvnili jeho samostatné umelecké pôsobenie v Prešove ako režiséra a dramaturga. ${ }^{34}$ Išlo

${ }^{29}$ Borodáč obsadil Chmelka po jeho príchode do SND hned’ do hlavných úloh: Eleméra Poludníckého v Stodolovej Maríne Havranovej (1941), či ešte predtým do ústrednej postavy Ostrovského komédie Vlci a ovce (Murzaveckij) ako partnera Ol'gy Borodáčovej (Murzavecká), čo, ako tvrdí Chmelko, spôsobilo v súbore „rozruch“, ked’že v Cramptonovi „zrejme som nikoho nenadchol“. Hra Vlci a ovce bola rozoskúšaná, nebola však premiérovaná z politických dôvodov (zákaz uvádzania ruských a sovietskych hier). Do postavy Poludnického sa vraj autor hry Ivan Stodola dožadoval obsadit’ Jána Jamnického. „Ale Borodáč nepovolil." Pozri CHMELKO, Andrej. V zajatí Tálie, s. 28.

30 "Helmer mi vyšiel ako postava nehotová, s ktorou som sa doma pred každou reprízou znova a znova boril.“ Pozri CHMELKO, Andrej. V zajatí Tálie, s. 32.

${ }^{31}$ Išlo o hru Kolega Crampton. Pozri tamže, s. 27.

32 „Nechápal som, prečo sa to robí. Ale inscenácia patrila do tých ,básnických', ktoré režisér vytvoril.“ Pozri tamže, s. 38.

${ }^{33}$ Tamže, s. 29.

${ }^{34}$ Viac k prvým sezónam prešovského divadla, a teda aj k Chmelkovmu pôsobeniu pozri HIMIČ, Peter. Divadelný život Prešova: Od počiatkov do polovice 20. storočia. 
síce o jasný realistický štýl, taký, aký videl u Borodáča ${ }^{35}$, niekol’ko inscenácií však vybočovalo z tejto línie. Boli to najmä Trasovisko Štefana Králika (1944) a Prúd Maxa Halbeho (1944), teda texty s imanenciou symbolistického javiskového spracovania. Ked’̌̌e Chmelko pôsobil aj ako dramaturg divadla, možno k tejto línii zaradit’ tiež Tanec nad plačom Petra Zvona (1944, réžia Dezider Stránsky), pričom sám Chmelko k ním prirad’uje aj Službohoncov Ivana Vazova (1944, pôvodný názov hry Na návšteve u ministra, réžia František Dadej) a vlastnú inscenáciu komédie Suchovo-Kobylina Krečinskij sa žení (1944). ${ }^{36}$ Prešovské Trasovisko bolo Králikovým celoslovenským debutom v profesionálnom divadle. Príbeh, kompozícia, postavy a jazyk sú poznačené realistickou dramatickou tvorbou, ale rámcovanie hry je symbolistické. Voda ako leitmotív „tečie“ príbehom i naprieč postavami. Chmelkova réžia sa pokúsila, slovami divadelného historika Vladimíra Štefka, „vyjst’ autorovmu štýlu v ústrety “37. Možno to usudzovat' aj z faktu, že Chmelko v snahe o akcentovanie univerzálnosti témy a posilnenie symbolistických prvkov hry vsunul do textu lyrické vložky z Puškinových a Zborovjanových ${ }^{38}$ básní. V Halbeho Prúde nahradil reálne zvuky, predpísané v scénických poznámkach, reprodukovanou hudbou, aby zvýraznil symbolistický charakter príbehu. Trasovisko aj Prúd sú hry, ktoré opierajú príbeh a tému o symboliku vody ako drsného, nekompromisného, zemitého živlu. Chmelkovi poskytli príležitost’ ukázat’ režisérske schopnosti na nerecyklovaných textoch (popri nich režíroval napr. hry Škriatok (1944) a Krečinskij sa žení, teda Borodáčovu dramaturgiu z ND). Obidve inscenácie boli pokusom o odklon od realistickej réžie, čo sa mu čiastočne podarilo, aj ked' len výnimočne, v prvých štyroch sezónach a v druhej polovici pät’desiatych rokov v košickom divadle.

Po príchode do Košíc sa Chmelkovo krátke „bezborodáčovské“ obdobie končí. Je síce prijatý na pozíciu umeleckého šéfa, režiséra, herca aj dramaturga činohry, ale Borodáčov vplyv mu prisudzuje pozíciu sekundanta, a to najmä v dramaturgickej rovine. Tento fakt však mobilizuje jeho režisérske ambície: usiluje sa zbavit Borodáčovej dominancie a zároveň aktivizovat’ tvorivý dialóg. Hned' prvé premiéry nového divadla ukázali, že Andrej Chmelko bude musiet takýto dialóg absolvovat’ aj sám so sebou. V priebehu štyroch dní premiéroval dva nové tituly: otváraciu Marínu Havranovú (1945) a Kristínu (1945) Paula Géraldyho. Kým inscenácia Stodolovej drámy mala všetky znaky realistickej réžie aj hereckej interpretácie, Kristína bola pre rodiace sa teleso výzvou, ked’̌̌e Géraldyho hry sú preniknuté lyrikou a vyžadujú skúsených interpretov, ovládajúcich verš a kultivovanú javiskovú reč. Vzhl’adom na krátkosť času i dátumovú blízkost’ oboch premiér Borodáč súhlasil s recyklovaním Chmelkovej prešovskej Kristíny z jesene 1944. Režisér Chmelko sa mohol už v Prešove opriet’ o kvalitný preklad začínajúceho Alberta Marenčina. Aj ked’ inscenácia nemá archivovanú kritickú reflexiu, o niekol'ko rokov neskôr ju Julo Zborovjan zaradil k prvým Chmelkovým modernistickým réžiám v Košiciach: „Vývojovou krivkou cez prúdy režisérskeho modernizmu, ktorý bol u Chmelka charakterizovaný poetickým

\footnotetext{
${ }^{35}$ Repertoár zostavil „po konzultácii s Jankom Borodáčom a znalcami prešovských pomerov, najmä s Antonom Prídavkom“. Pozri CHMELKO, Andrej. V zajatí Tálie, s. 45.

${ }^{36}$ CHMELKO, Andrej. Divadlo na východnom Slovensku, s. 98.

37 ŠTEFKO, Vladimír. Slovenské činoherné divadlo 1938 - 1945. Bratislava : Národné divadelné centrum, 1993, s. 122. ISBN 80-85455-08-0.

${ }^{38}$ Ide o už spomínaného Jula Zborovjana, básnika a prekladatel’a, neskoršieho spolupracovníka Andreja Chmelka a Janka Borodáča v Košiciach ako dramaturga činohry.
} 


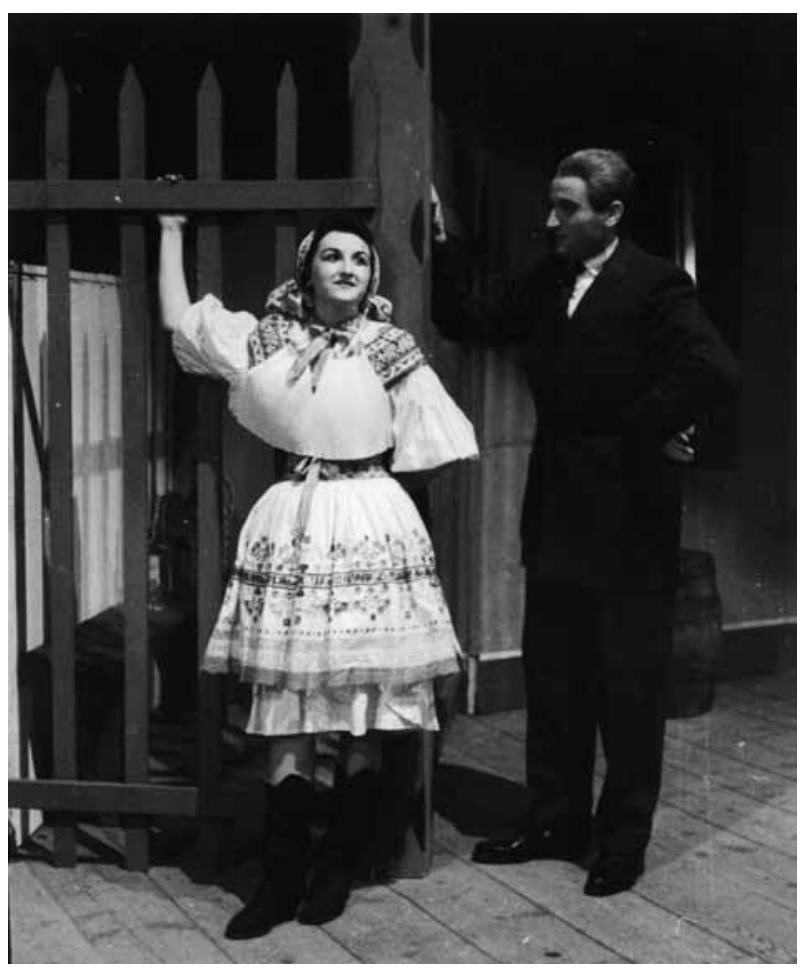

Martin Kukučín - Andrej

Chmelko: Bacúchovie dvor.

ND v Košiciach, premiéra 15.

5. 1948. Réžia Andrej Chmelko.

Beatrica Bočová, František Greguš.

Foto archív Štátneho divadla

Košice.

realizmom (Kristína, Veža, Hladaj seba), dostal sa k svojsky osobitému štýlu, ktorý sa vyznačuje pevnou ideovou a umeleckou líniou, správne vyzdvihujúcou základné prvky dramatického konfliktu (...).“39 Je prekvapujúce, že bilancujúci Zborovjan nezaradil k spomínaným Chmelkovým réžiám aj celoslovenskú premiéru hry Petra Karvaša Hra o básnikovi (1946). Bola to autorova dramatická prvotina, napísaná počas 2. svetovej vojny a pod pseudonymom ponúknutá ND. Už Chmelkov výber Karvašovho textu predznamenáva protiváhu tradičnej borodáčovskej dramaturgie. Hra bola v dovtedajšej slovenskej dramatike nová nielen tematickým zameraním, ale najmä kompozičnou (formálnou) rovinou, jazykom, dramatickým personálom, pričom divadelná história jej priznala „aj zjavný intelektuálny rozmer “40. Janko Borodáč, člen poroty na súbeh novej pôvodnej hry (1943), považoval Karvašov dramatický text za "experiment impresionistického žánru“, s tendenciou k epike, pričom autor "viacej dbá o scénický efekt, ako o myšlienku“. ${ }^{41}$ Napriek tomu navrhol zaradit hru do repertoáru ND v Bratislave. V tomto kontexte si Chmelko uvedomoval, že hra si vyža-

${ }^{39}$ ZBOROVJAN, Julo. Informatívne o činohre. In Národné divadlo v Košiciach : Jubilejné číslo programu ND v Košiciach. Košice : Pravda, 1955, s. 47.

${ }^{40}$ JABORNÍK, Ján - ČAHOJOVÁ, Božena. Peter Karvaš. In ŠTEFKO, Vladimír a kol. Dejiny slovenskej drámy 20. storočia. Bratislava : Divadelný ústav, 2011, s. 358. ISBN 978-80-89369-36-2.

${ }^{41}$ LAJCHA, Ladislav. Dokumenty SND 1939 - 1945 : Divadlo v rokoch vojny, s. 276 - 277. Borodáč nepostrehol literárne a scénické kvality textu, ako to bolo v prípade iného člena poroty, Jozefa Felixa, ktorý oceňoval autorovu prácu s „novými dramatickými prostriedkami, viac expresívnou skratkou, než širokým rozvádzaním situácií“. Tamže, s. 258. 
duje nie každodenný spôsob réžie. Preto výrazne pracoval so svetlom, s farebnostou (kritika písala o polorealistickom riešení scény), štylizované herectvo sa prejavilo najmä vo využití pohybových prostriedkov. ${ }^{42}$ Napriek dovtedajším Chmelkovým zaujímavým prácam (Trasovisko, Prúd, Kristína) išlo preňho o prvú väčšiu výzvu smerom k súčasnej réžii aj dramaturgii.

Andrej Chmelko režíroval aj celoslovenskú premiéru hry Veža (1947) od d’alšieho významného dramatika, Júliusa Barča-Ivana. Veža patrí k okruhu autorových hier, ktoré súčasná literárna a divadelná veda označuje ako drámu s katastrofickou a apokalyptickou témou. ${ }^{43} \mathrm{~V}$ tomto kontexte možno ocenit Chmelkovu dramaturgickú odvahu aj prácu, ked’že Barča-Ivana aktivizoval zaradením nedokončenej hry na repertoár, „len čo autor naznačil jej obsah a ideové zameranie ${ }^{“ 44}$. Režisér si uvedomoval náročnost' hry, nielen pre hercov a inscenátorov, ale aj pre obecenstvo. Barča-Ivana vnímal ako najviac vyzretého súčasného slovenského dramatika, niektoré jeho hry (Matka, Neznámy, Dvaja, Veža) boli podla Chmelka „na úrovni medzinárodnej“45. Po prvýkrát bol konfrontovaný s vel'kým obsadením (v košickej inscenácii účinkovalo okolo 50 l'udí). Práve tento fakt, a tiež otázka scénického riešenia (Ladislav Šestina) sa ukázali ako najväčšie výzvy. Dobové ohlasy považujú kolektívne scény za nezvládnuté, prednes za patetický, scénu za popisnú. ${ }^{46}$ Zdá sa, že autorov rukopis režiséra zaskočil: Chmelko, poznajúc dovtedajšiu Barčovu-Ivanovu tvorbu, neočakával také tematicky komplikované, personálne bohato komponované a scénicky monumentálne dielo. Napriek náročnosti predlohy a inscenačnému výsledku si velmi jasne uvedomoval presahy biblickej fabuly do povojnovej skutočnosti. ${ }^{47} \mathrm{~V}$ neskorších spomienkach sa o tejto svojej inscenácii zmieňuje len okrajovo.

K tým Chmelkovým inscenáciám, ktoré polemizovali s borodáčovskou realistickou réžiou, možno zaradit’ aj hru Luigiho Pirandella Hladaj seba (1948) či Zvonov Tanec nad plačom (1946). Najmä Peter Zvon mu bol blízky. V Bratislave videl Jamnického inscenáciu hry, v Prešove hral Grófa Richarda (réžia Dezider Stránsky). V Košiciach sa pokúsil, aby inscenácia „nebola parafrázou ani Jamnického (...), ani Stránskeho $(\ldots)^{448}$. Napriek tomu, že podla názoru recenzenta nemal súbor interpretov na „náročnejšie lyrické úlohy“, režisér Chmelko dobre rytmizoval dialógy a scény, avšak Ol'ga Borodáčová „nevedela sa zbavit’ pátosu“" ${ }^{\prime 49}$. Najvýraznejším dramaturgickým zásahom bola reakcia na nové politicko-spoločenské pomery. Aktualizácia išla tak d’aleko, že napríklad Tajomník dr. Pysk bol oblečený v uniforme Hlinkovej mládeže.

\footnotetext{
${ }^{42}$ Autor neuvedený. Karvašova „Hra o básnikovi“. In Východoslovenská Pravda, roč. 2, č. 60, s. 4, 13. 3. 1946.

${ }^{43}$ ROBERTSOVÁ, Dagmar. Katastrofická a apokalyptická téma v slovenskej dráme 1945 - 49 : P. Karvaš, J. Barč-Ivan, J. Váh. In Slovenské divadlo, 2006, roč. 54, č. 2, s. 285 - 311.

${ }^{44} \mathrm{CHMELKO}$, Andrej. S Barčom do tretej sezóny. In Bulletin ND v Košiciach č. 1 : Július Barč Ivan: Veža. Košice : ND v Košiciach, 1947/48, premiéra 20. 9. 1947, s. 8. Pozri aj CHMELKO, Andrej. Retrospektívy a perspektívy, s. $47-48$.

${ }^{45}$ Tamže.

${ }^{46}$ Aj ked' dobové fotografie $\mathrm{z}$ archívu ŠD Košice tento fakt (scéna) potvrdzujú, tažko hovorit’ o fundovaných recenziách. V tom období košickú činohru v miestnej tlači pokrýval najmä Ján Skalka, autor propagandistických a schematických hier (najmä Kozie mlieko), ktorý pod skratkou -sk- napísal dva postrehy vo Východoslovenskej Pravde (23. 9. a 24. 9. 1947). Popri ňom priniesol ambicióznejší rozbor ešte Gabriel Rapoš (pod skratkou -groš-) v Čase (4. 11. 1947).

${ }^{47}$ „(...) cítime, že je to svet dneška (...)“. Pozri CHMELKO, Andrej. S Barčom do tretej sezóny, s. 8.

${ }^{48}$ CHMELKO, Andrej. V zajatí Tálie, s. 91.

49 -sk-. „Tanec nad plačom“ na scéne VND. In Východoslovenská Pravda, roč. 2, č. 147, s. 4, 26. 6. 1946.
} 
Takáto časová konkretizácia zbavovala pôvodinu univerzálnosti a do istej miery aj poetickosti. Podl’a dobových fotografií ani archaická scénografia herca Jána Bzdúcha nedosahovala estetické kvality prešovskej inscenácie so scénou Martina Brezinu.

V prvých rokoch existencie košickej činohry (1945 - 1949) bol Janko Borodáč zahltený riaditel'skými povinnostami. Po nútenom odchode z Bratislavy sa tažko zmieroval s pocitovanou krivdou. Jeho inscenácie v tomto období nezaznamenali výraznejší úspech, pohyboval sa „dost’ na pokraji popisného realizmu, ba nebol skúpy ani na prvky naturalizmu... ${ }^{150}$. Andrej Chmelko sa plne sústredil nielen na umelecké vedenie činoherného súboru, ale ako režisér vycítil aj umeleckú príležitost: „,...) tvoril divadlo síce $\mathrm{v}$ zákonitostiach realistických postupov, ale už s nádychom symbolizujúcej poetizácie ${ }^{\prime 51}$. V takto nastavenej del'be medzi ním a Borodáčom chcel na jeseň 1948 naštudovat’ hru Leopolda Laholu Štyri strany sveta. Borodáč, zažívajúci po februárovom prevrate ataky na svoju apolitickost', sa v očiach novej moci snažil rehabilitovat', a preto k výročiu Októbrovej revolúcie napokon Lalohovu hru režíroval on, zatial' čo Chmelkovi prenechal Karvašovu Baštu (1948). Borodáč však nevycítil existencialistické a hlboko etické posolstvo hry z tzv. povstaleckej tematiky povojnovej slovenskej drámy. Nepriniesla mu ani umelecký, ani politický úžitok. Ešte aj vo svojich memoároch, písaných niekol'ko rokov po krutom období nastupujúceho komunizmu, inscenáciu nespomína. ${ }^{52}$ Táto umelecká a v podstate aj l’udská prehra Borodáča, ktorý bol v umeleckých otázkach vždy konzistentný, akoby aktivizovala jeho režisérske schopnosti. Po roku 1948 prichádzajú najvýznamnejšie inscenácie jeho košického obdobia: Hviezdoslava tragédia Herodes a Herodias (1949), Chalupkovo Kocúrkovo (1949), Tajovského Statky-zmätky (1950), Záborského Najdúch (1952), no najmä Čechovove Tri sestry (1952) a Gogolov Revízor (1952)..$^{53}$ Naopak, Chmelkove modernistické pokusy zaznamenávali zostupnú trajektóriu a v jeho réžiách sa začali „objavovat’ aj niektoré znaky dobových zjednodušujúcich tendencií uplatňovania socialistického realizmu“54.

Ambivalentný, krížový vývoj hlavných režisérskych protagonistov prvej dekády košickej činohry je potrebné vnímat i na pozadí spoločensko-politických zmien. Obdobie do februárového prevratu (1948) s jeho demokratickým charakterom i radostou z novonadobudnutej slobody umožňovalo Chmelkovi, aj ked' reprezentantovi realistickej školy, realizovat' vlastný dramaturgický program a budovat si vlastný režisérsky štýl. Borodáč sa musel venovat budovatel'ským povinnostiam - ako riadi-

${ }^{50}$ GOJDA, Mikuláš Štefan. Dvadsat rokov činohry ŠD. In ZBOROVJAN, Julo a kol. 20 rokov Štátneho divadla v Košiciach. Košice : Východoslovenské vydavatel'stvo, 1965, s. 32.

${ }^{51}$ Tamže. Gojda k tejto línii - popri Tanci nad plačom - prirad’uje aj Marínu Havranovú a Súd bez pomsty (1947) Ely Klenovej.

${ }^{52}$ Pri bilancii sezóny 1948/1949 spomenie len dve pôvodné hry: Herodes a Herodias a Baštu. Pozri BORODÁČ, Janko. Spomienky, s. 252. Andrej Chmelko spomína, ako bol Borodáč po premiére Laholovej hry predvolaný pred stranícke vedenie, kde mu bolo vyčítané, že Yorika vo finále hry nemôže nezastrelit nemeckého vojaka. „Záver bude údernejší, revolučnejší. Také umenie dnes potrebujeme, tomu nás učí Február.“ V reprízach už Yorika striel'al, a tak sa Štyri strany sveta stali „hrou socialisticko-realistickou“. Pozri CHMELKO, Andrej. Spoza opony. Vydal Andrej Chmelko, 1996, s. 50.

${ }_{53}$ Zaujímavú spomienku na režijnú koncepciu Revízora priniesol M. Š. Gojda, ktorému Borodáč vysvetloval, že mu ide o „náznakový realizmus, čiže skratku, kým mnohé jeho inscenácie predtým boli u neho poznačené až naturalizovaním toho, čo on sám nazýval systémom Stanislavského“. Pozri GOJDA, Mikuláš Štefan. Dvadsat’ rokov činohry ŠD, s. 32.

${ }^{54}$ JABORNÍK, Ján. Tridsatpät rokov činohry. In 35 rokov Štátneho divadla v Košiciach. (Ed. Štefan Fejko.) Košice : Štátne divadlo, 1980, s. 6. 


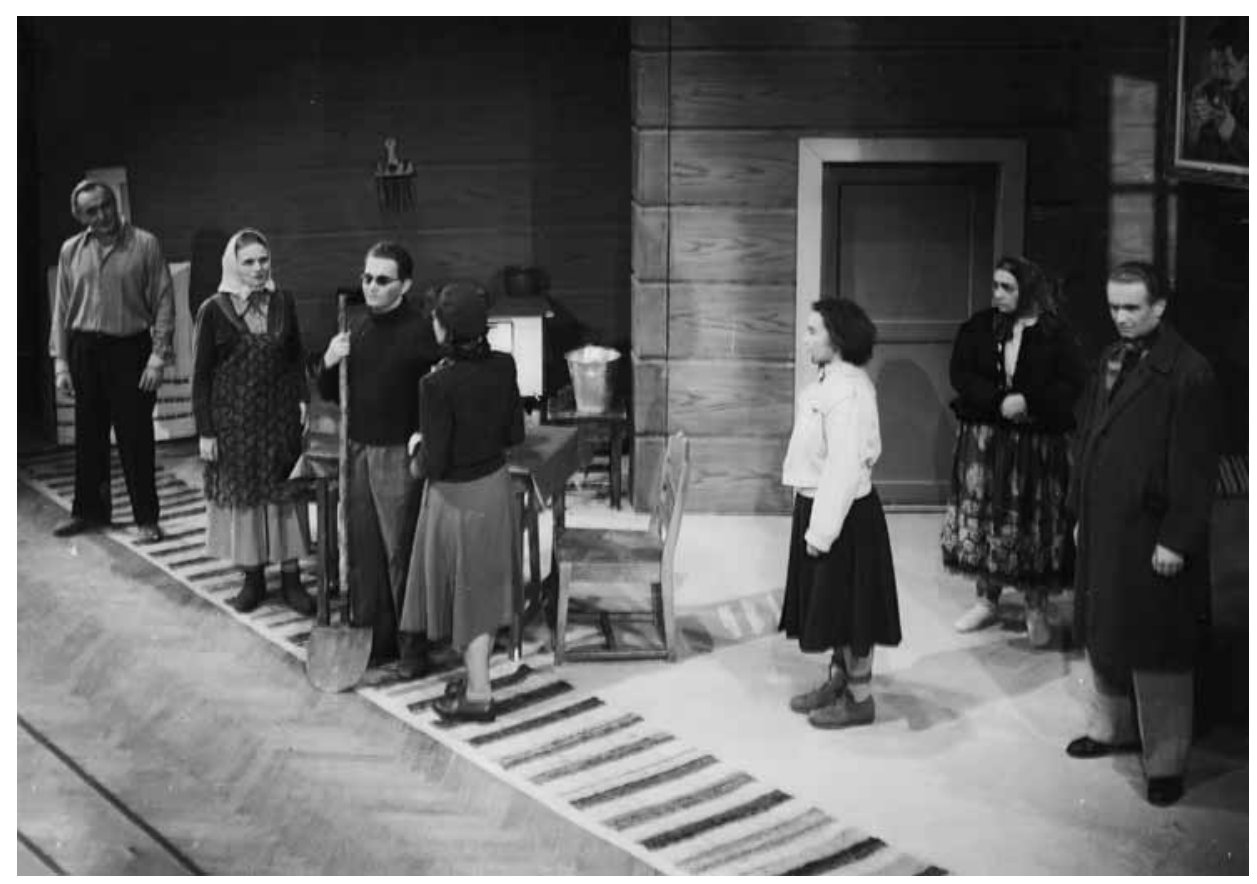

Andrej Chmelko: Po širokej kolaji. ND v Košiciach, premiéra 16. 9. 1950. Réžia Andrej Chmelko. Foto archív Štátneho divadla Košice.

tel' navonok, ako umelec dovnútra. Súčasne prebiehajúce personálne obsadzovanie troch súborov ho vyčerpávalo, na úradné povinnosti nebol zvyknutý. Aj jeho prvé košické réžie (1945 - 1947) s kolísavými inscenačnými výsledkami v podstate recyklovali bratislavskú dramaturgiu. Po roku 1948 sa tlak na jeho osobu stupňoval. Odolával tak ponukám na vstup do komunistickej strany, ako aj útokom nových, „progresívnych" síl v spoločnosti. Niekol'kokrát hrozil demisiou, čo sa pre citlivost’ témy (išlo o zakladatela slovenského profesionálneho divadla) muselo riešit’ na najvyšších miestach. Tieto tlaky ho umelecky aktivizovali: vedel, že iba kvalitný výsledok bude štítom pred rozbiehajúcou sa ideologickou mašinériou a ludskou ostrakizáciou. Pre komunistu Andreja Chmelka obdobie po roku 1948 znamenalo, paradoxne, začiatok jeho postupného umeleckého stagnovania. Po odchode Borodáča, aj v dôsledku Chmelkovej neschopnosti pochopit’ či aspoň akceptovat' nastupujúce moderné prúdy v dráme, réžii a herectve, to už boli roky ,jasnej revolty proti mnohým módnym prúdom v našom divadelníctve ${ }^{\prime \prime 55}$.

Hoci teatrológ Ján Jaborník pozitívne hodnotí nespornú zakladatel'skú a budovatel'skú činnost' Janka Borodáča v Košiciach, uvedomuje si, že práve prvá dekáda divadla bola „ochudobnená o modernú, progresívnu, vývinotvornú líniu“56. Borodáč zároveň vplýval na profiláciu činoherného súboru, ktorý na ním položených základoch staval dlhé roky. Hlavným problémom však bola absencia výraznej umelec-

\footnotetext{
${ }^{55}$ GOJDA, Mikuláš Štefan. Dvadsat’ rokov činohry ŠD, s. 35.

${ }^{56}$ JABORNÍK, Ján. Minulost’ a prítomnost' košickej činohry. In Slovenské divadlo, 1973, roč. 21, č. 3, s. 307.
} 
kej osobnosti, ktorá by, najmä v réžii, priniesla nové podnety a metódy práce. Eklatantným príkladom toho sú práve Chmelkove réžie, ktoré po istých nádejných náznakoch v prvých rokoch uviazli, prakticky až do roku 1968, v konzervovaní štýlu naturalistického, opisného realizmu. Ako konštatuje Jaborník, Chmelko nemal „prepotrebné pedagogické, teda výchovné, formujúce, tvorivo obohacujúce a inšpirujúce schopnosti ${ }^{\text {"57. }}$.

K pochopeniu Chmelkovho umeleckého vývinu je potrebné spomenút aj jeho literárne ambície, ktoré mali skutočne široký záber (román, divadelné hry, rozhlasové pásma, dramatizácie, preklady, odborné práce). Pre potreby košického divadla upravil hru Martina Kukučína Bacúchovie dvor (1948) a zdramatizoval novelu Boženy Slančíkovej-Timravy Hrdinovia (1953). Napísal dobovú agitku Po širokej kol’aji (1950), ktorá už plne reflektovala potrebu tzv. novej drámy o nových l'ud’och. Chmelko poznal Borodáčove úpravy slovenskej klasiky, ktoré často išli za pôvodný fabulačný rámec, ba niekedy aj nad ideovo-estetický zámer autora. Možno i to ho posmelilo vo výraznejšom časovom posunutí Timravinej novely. Ako konštatuje divadelný historik Vladimír Štefko, predvojnový „príbeh dofabuloval, použijúc motívy aj z iných Timraviných próz", a posunul ho až do roku $1918 .{ }^{58}$ Napriek Chmelkovým textovým úpravám sa však aj réžie Hrdinov a Po širokej kol’aji zarad'ujú k málo progresívnej tvorbe jeho prvého obdobia, ba čo viac, anticipujú stagnáciu a regres.

Andrej Chmelko je tiež autorom odborných prác. Na rozdiel od Borodáča, ktorý volil subtílne formy (štúdie, režijné knihy, rozhovory, novinové a časopisecké články), Chmelko sa do konca života (1998) pokúšal, popri množstve článkov uverejnených v časopisoch Slovenská reč a Naše divadlo, presadit’ aj ako teoretik a historik. ${ }^{59}$ V monografii Tvorivé problémy divadla (1962) sumarizuje vlastné poznatky z oblasti javiskovej reči, dramaturgie, réžie, (...). Práca je však nedostatočne teoreticky vyargumentovaná, dogmatická, štýlovo eklektická, trpí vysokou mierou ideologizácie. Tá sa prejavila aj v stati o divadelnej kritike, v ktorej sa popri inom píše: „Socialistický kritik musí poznat jediné svetlo: červenú žiaru komunizmu." ${ }^{\prime 60}$ Táto ideologická báza dlhé roky problematizovala vztah košického divadla ku kritike, najmä k mladej a predovšetkým k tzv. bratislavskej. ${ }^{61}$ Pravda, aj Janko Borodáč sa často staažoval na kritiky a kritikov. Po prvých budovatel'ských rokoch $(1945$ - 1947) však kvitoval rastúci záujem o Košice a uvádzal, podla neho, kladné príklady analýz inscenácií, najmä tých, ktoré sledovali vývoj v diachrónnom i formotvornom kontexte. Nevstupoval do zovšeobecňujúcich sporov s nastupujúcou generáciou kritikov, polemizoval skôr s jednotlivostami a jednotlivcami (výnimkou boli len Rudolf Mrlian a niektorí regionálni prispievatelia). Andrej Chmelko si po rokoch v riaditel'skej funkcii vypracoval určitý druh dištancie, ktorá sa v istých obdobiach striedala so zvláštnym druhom rezistencie alebo „kritiky kritiky“. Ešte i v roku 1960, v čase postupného uvol'ňovania ideologického zovretia slovenského divadla, postuluje aj tieto myšlienky: „Od

\footnotetext{
${ }^{57}$ Tamže, s. 309.

58 ŠTEFKO, Vladimír. Dráma slúžkou ideológie 1948 - 1960. In ŠTEFKO, Vladimír a kol. Dejiny slovenskej drámy 20. storočia, s. 341 .

${ }^{59} \mathrm{CHMELKO}$, Andrej. Tvorivé problémy divadla. Košice : Krajské nakladatel'stvo, 1962; tiež CHMELKO, Andrej. Divadlo na východnom Slovensku.

${ }^{60}$ CHMELKO, Andrej. Tvorivé problémy divadla, s. 98.

${ }^{61}$ Viac $k$ tejto téme pozri HIMIČ, Peter. Tak d’aleko a predsa tak blízko. In Ján Jaborník: Historik, teoretik a kritik divadla. Bratislava : Divadelný ústav, 2018, s. 101 - 111. ISBN 978-80-8190-041-9.
} 


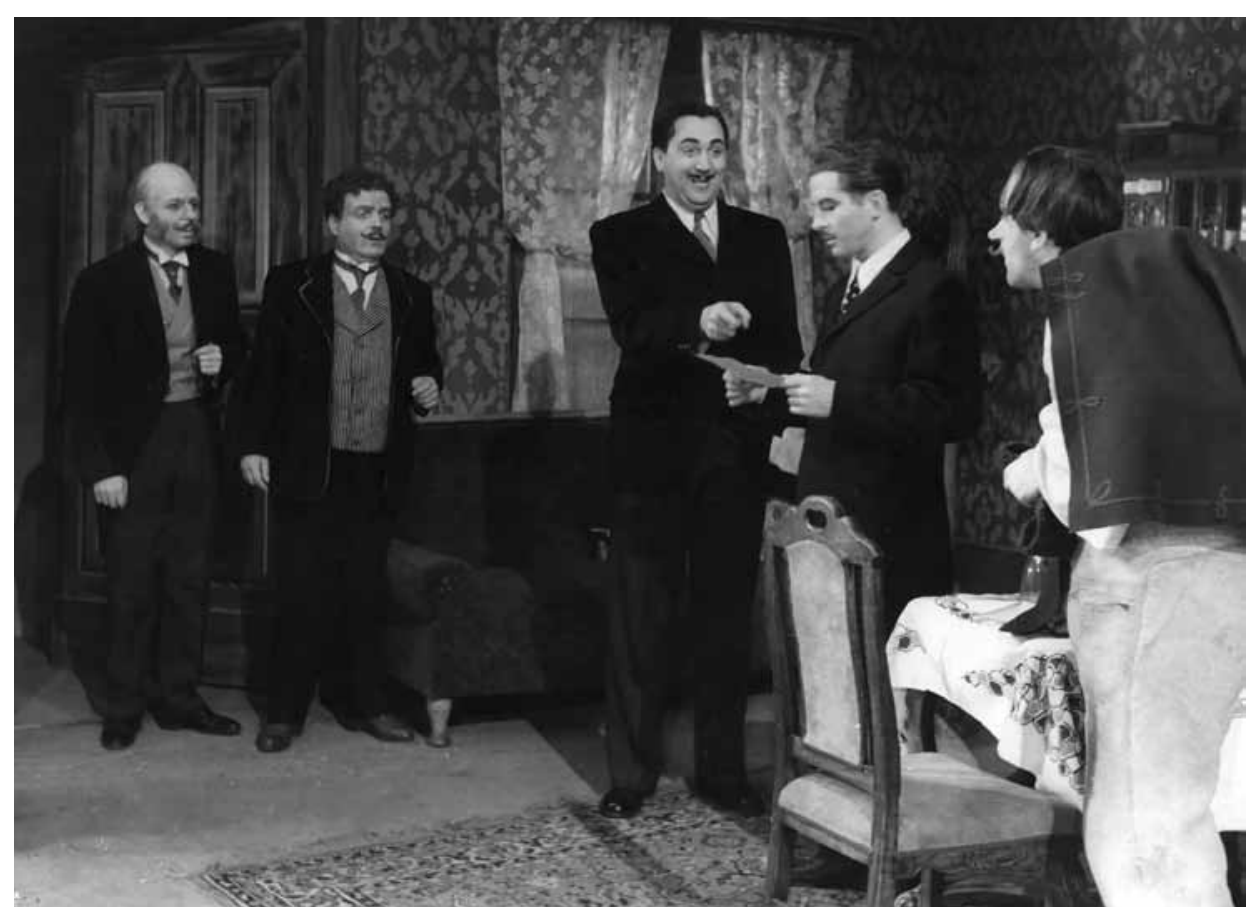

Božena Slančíková Timrava - Andrej Chmelko: Hrdinovia. ND v Košiciach, premiéra 31. 1. 1953. Réžia Andrej Chmelko. Vojtech Pagáč (Elek Klipkáč), František Dadej (Imrich Moller), František Kabrhel' (Laci Baláň), Ondrej Grega (Štefan Širický). Foto archív Štátneho divadla Košice.

jednej modly (Stanislavskij) prešli k druhej (Brecht) ... Tak sa stalo, že v r. 1956 až 1960 odsúdili kritici vel’a dobrých inscenácií (alebo ich obišli bez povšimnutia, čo je ešte horšie!) len preto, že im tam chýbala metafora alebo - podla nich - pocit súčasnosti. “62 Kritizoval nezáujem Bratislavy o košické inscenácie a zároveň cítil generačnú spriaznenost’ mladých teatrológov s novou režisérskou generáciou, ktorá nastúpila do Štátneho divadla v druhej polovici pätdesiatych rokov (Jozef Pálka, Oto Katuša). Stanislav Vrbka pri hodnotení Tvorivých problémov divadla replikoval Chmelkove kontinuálne ponosy: „(...) kvalita jeho teoretických postulátov je priamo úmerná kvalite jeho inscenácií a že teda nemusí v tom vidiet’ nijaké osobné sympatie, ak väčšina kritikov cestuje do Košíc za predstaveniami jeho mladších kolegov, režisérov, nehonosiacich sa neomylnostou (...). ${ }^{\text {63 }}$

Pri komparácii umeleckých paralel a diferencií Borodáča a Chmelka si nemožno nevšimnút ich hereckú interpretáciu. Obidvaja patrili k predstavitel’om realistického

${ }^{62}$ Andrej Chmelko v Jubilejnom bulletine k 15. výročiu košického divadla v septembri 1960. In FERKO, Tibor. Divadelné letopisy mesta Cassa, Caschau, Kassa, Košice v súvislostiach dejín 1557 - 1945 - 2010, s. 908.

${ }^{63}$ VRBKA, Stanislav. O kurióznom teoretizovaní jedného divadelníka. In Kultúrny život, roč. 18, č. 17, s. 9, 27. 4. 1963. Andrej Chmelko spomína, že sa ho Vrbkova kritika dotkla a znechutila, vyvažuje ju listom profesora Jána Stanislava, ktorý mu napísal: „Nesúhlasíme s kritikou v Kultúrnom živote!“ Boj staršej a mladšej generácie bol teda na začiatku šest’desiatych rokov širším fenoménom. Pozri CHMELKO, Andrej. V zajatí Tálie, s. 227. 
až naturalistického herectva, s výraznou snahou o psychologický prístup ku kreovaniu postavy. Obidvaja boli epigónmi Stanislavského metódy, aj ked' Chmelko vo viac deformovanej, vylúhovanej podobe. Napriek istým fyzickým predpokladom (Borodáčova chudá, vysoká postava; Chmelko ako fyzicky prítažlivý, hrdinský typ) sa dokonca, odhliadnuc od pár menších úloh, nepresadili ani pred filmovou a televíznou kamerou.

A napokon tým, čo spája Janka Borodáča s Andrejom Chmelkom, je ich memoárová spisba. Obaja zanechali rozsiahle biografické práce, ktoré dodnes prekvapujú rozsahom i šírkou tematického záberu. Kým Borodáč je viac faktografický, Chmelko v duchu celoživotnej literárnej ambície špikuje svoje práce glosami, postrehmi, v časových skokoch ich štýlovo rozkolísava a jazykovo ornamentizuje. Obaja často fabulujú, fakty (a ich interpretácie) prispôsobujú na svoj obraz, pocitujú určité nedocenenie a neschopnost' okolia reflektovat' ich zásluhy na divadelnom poli. V komplexe Chmelkovej celoživotnej spomienkovej tvorby však možno badat väčšiu zatrpknutost' než u Borodáča, a to najmä smerom k odbornej responzii. Po roku 1989 Chmelko niektoré pohl'ady na vlastnú tvorbu a činnost’ reviduje, no v zásade svoj prínos nerelativizuje. ${ }^{64}$ Výnimku tvorí len pár postrehov o období schematizmu a politických represálií. Napriek tomu, memoárové dielo zakladajúcich osobností profesionálneho divadla na východnom Slovensku je v slovenských podmienkach výnimočné, obsahovo nasýtené, a poskytuje bazálny materiál, bez ktorého sa nedajú napísat' slovenské divadelné dejiny.

Po Borodáčovom odchode z Košíc bol Chmelko ako riaditel' postavený pred novú výzvu: obsadit' uvolnený post umeleckého šéfa činohry relevantnou umeleckou osobnostou. Dlhodobo bolo tažké preklenút neochotu a aj istú nedôveru bratislavských režisérov voči hereckým dispozíciám súboru. Od roku 1953 sa vo vedení činohry v rýchlom slede striedali domáci herci (Ján Bzdúch, Jozef Hodorovský), Chmelko dokonca vycestoval za Jánom Jamnickým („súbor musí viest’ autorita“65), no ten ponuku taktiež odmietol. Až príchod Jozefa Pálku v roku 1957 (súčasne prijal aj miesto umeleckého šéfa) a dramaturgičky Margity Maeyrovej znamenal na pár rokov určitú stabilizáciu súboru. Po ich odchode sa problém s nájdením relevantnej režisérskej osobnosti opakoval. Posledné roky Chmelkovho pôsobenia na čele košického divadla boli poznačené rutinou (aj v riadiacej práci) a umeleckou stagnáciou. Hektické udalosti roku 1968 mu dokonca neumožnili dokončit’ kalendárny rok vo funkcii: už ku koncu októbra, necelé tri týždne pred šest’desiatkou, bol prinútený (na vlastnú žiadost'!) skončit’ ako riaditel' a koncom roka znechutený odišiel.

\section{Záver}

Ako sa ukazuje, vzt’ah Borodáč - Chmelko nebol jednoznačný ani v umeleckej, ani v l’udskej rovine. Borodáč považoval Chmelkovu misiu na východe (Prešov) za

${ }^{64}$ Ide najmä o Chmelkove práce Spoza opony a výber článkov a úvah Retrospektívy a perspektívy, ktoré v roku 1968 zostavil a v roku 1969 pripravil do tlače Julo Zborovjan. Tie napokon vyšli vlastným nákladom autora až v roku 1997 s doslovom a korektúrami, ktoré sa na niektorých miestach snažia reflektovat nové pomery v demokratickom a samostatnom štáte.

${ }^{65}$ CHMELKO, Andrej. V zajatí Tálie, s. 174. 
možné riešenie saturovania profesionálnych postupov, domnievajúc sa, že práve profesionál z prostredia Národného divadla bude zárukou umeleckých štandardov. Jeho skúsenosti logicky využil aj pri budovaní košickej činohry. Neskôr sa Chmelko umelecky osamostatnil, stal sa istejším i v riadiacich činnostiach a po roku 1948 vnášal ideologické aspekty do riadiacej aj umeleckej práce. Borodáč si zachoval dostatočný odstup, snažil sa Chmelka vyslat' na d’alšie zakladatel'ské misie, no neoznačil ho za svojho nástupcu. Zásadným umeleckým putom, ktoré ich viaže, je realistická metóda, pričom v Chmelkovom prípade išlo postupom rokov o jej vulgarizovanú podobu. ${ }^{66}$ Kým Borodáč ju mal ujasnenú, Chmelko ju skôr tušil. Výsledkom boli rozkolísané umelecké výsledky a stagnácia činoherného telesa. Ak bol Borodáč, ako tvrdí divadelný historik Karol Mišovic, „po estetickej stránke človekom 19. storočia, po stránke ludskej rigoróznym, konzervatívnym“" ${ }^{\prime 67}$ tak Chmelkovi rovnaká konzervatívnost' zabránila rozvinút mierne záblesky progresu a stat' sa umelcom 20. storočia. Napriek tomu, Andrej Chmelko poctivo pristupoval $\mathrm{k}$ budovaniu profesionálneho divadla na východnom Slovensku, hladal možnosti jeho rozvoja, snažil sa pozývaním iných režisérov naštartovat’ herecký potenciál činohry. Riaditel’ská funkcia ho evidentne vzd’al’ovala od koncepčnej režisérskej práce, ked’že dlhé obdobia suploval aj umelecké vedenie činohry. Janko Borodáč jeho prácu sledoval, ale nijako do nej nezasahoval. Sám sa vyrovnával s postupným nezáujmom o svoju osobu. Obidvaja zažili nástup novej režisérskej a hereckej generácie na prelome pätdesiatych a šest’desiatych rokov. Bolo evidentné, že onen nový vlak už nestál na ich nástupišti.

\section{JANKO BORODÁČ AND ANDREJ CHMELKO. TWO ROADS - ONE DIRECTION}

\section{Peter HIMIČ}

The study deals with the not very well documented relationship between the founders of Slovak professional theatre following World War II. The relationship between Janko Borodáč, director of the East Slovak National Theatre in Košice, and the artistic director, Andrej Chmelko, have long been perceived as art-related, predominantly only in one direction, with the clear dominance of Borodáč. The work analyzes the artistic and human interconnections of their relationship contributing to the decisive moments in the creation of the Košice Theatre, which had for many years determined the artistic level of all its ensembles.

Peter Himič

Fakulta dramatických umení

Akadémia umení

Horná 95

97401 Banská Bystrica

e-mail: himicpeter@gmail.com

${ }^{66}$, ,(..) všetko, čo on nerežíroval v košickom divadle, zaváňa ak nie podozrivou modernostou, tak aspoň eklekticizmom." Pozri VRBKA, Stanislav. O kurióznom teoretizovaní jedného divadelníka, s. 9.

${ }^{67}$ MIŠOVIC, Karol. Ján Borodáč a jeho prvé kroky v živote i v divadle, s. 101. 